\title{
UV-B radiation arising from stratospheric ozone depletion influences the pigmentation of the Antarctic moss Andreaea regularis
}

\author{
K. K. Newsham
}

British Antarctic Survey, Natural Environment Research Council, High Cross, Madingley Road, Cambridge, CB3 OET, UK

E-mail: k.newsham@bas.ac.uk

Fax: $+44(0) 1223362616$

\begin{abstract}
Changes to the radiative environment arising from stratospheric ozone $\left(\mathrm{O}_{3}\right)$ depletion and subsequent associations between these changes and the pigmentation of the moss Andreaea regularis were measured in late austral spring and early summer 1998 at Rothera Point on the western Antarctic Peninsula (67E S, 68E W). A strong relationship between $\mathrm{O}_{3}$ column depth and the ratio of UV-B to PAR irradiance $\left(\mathrm{F}_{\mathrm{UV}-\mathrm{B}} / \mathrm{F}_{\mathrm{PAR}}\right)$ was recorded at ground level $\left(r^{2}=92 \%, P<0.001\right)$. Weaker, but significant, associations between $\mathrm{O}_{3}$ column depth and ground level unweighted and biologically effective UV-B radiation (UV-B $\left.\mathrm{BE}_{\mathrm{BE}}\right)$ were also found. Regression analyses indicated that $\mathrm{F}_{\mathrm{UV}-\mathrm{B}} / \mathrm{F}_{\mathrm{PAR}}$ was the best predictor for concentrations of UV-B screening pigments and total carotenoids extracted from plant tissues. Concentrations of these pigments were loosely $\left(r^{2}=c .30 \%\right)$ but significantly $(P<0.01)$ positively associated with $\mathrm{F}_{\mathrm{UV}-\mathrm{B}} / \mathrm{F}_{\mathrm{PAR}}$. Concentrations of UV-B screening pigments were also positively associated with irradiances and daily doses of unweighted UV-B and UV-B $\mathrm{B}_{\mathrm{BE}}$ radiation. The concentrations of chlorophylls $a$ and $b$ were apparently unaffected by $\mathrm{O}_{3}$ depletion. The data derived from this study suggest that changes to the radiative environment associated with stratospheric $\mathrm{O}_{3}$ depletion influence the pigmentation of $A$. regularis. As a corollary, flavonoids are shown to be present in tissues of $A$. regularis.
\end{abstract}

Key words Bryophyte, carotenoids, flavonoids, UV-B screening pigments 


\section{Introduction}

Halocarbon release to the atmosphere has caused widespread depletion of stratospheric ozone $\left(\mathrm{O}_{3}\right)$ since the early 1980s (World Meteorological Organization 1999). Substantial O $\mathrm{O}_{3}$ reductions, arising from photochemical catalysis by reactive chlorine and bromine species on the surfaces of polar stratospheric clouds, have been recorded over Antarctica, leading to the annual springtime 'ozone hole' (Farman et al. 1985). Since $\mathrm{O}_{3}$ absorbs biologically damaging solar ultraviolet-B (UV-B) radiation $(280-315 \mathrm{~nm})$, stratospheric $\mathrm{O}_{3}$ depletion leads to increased irradiances of UV-B received at the Earth=s surface (World Meteorological Organization 1999).

During the past two decades considerable effort has been invested in determining plant response to simulated $\mathrm{O}_{3}$ depletion. The two main experimental approaches used have been to apply supplemental UV-B radiation to plants from fluorescent UV lamps or to filter UV-B from solar radiation, typically with plastic screens (Rozema et al. 1999). These artificial exposures have suggested that $\mathrm{O}_{3}$ depletion increases foliar concentrations of UV-B screening pigments, typically flavonoids, but has little effect on the photosynthesis and growth of many plant species (Caldwell and Flint 1994). However, artificial exposures are often confounded by methodological problems. For example, low irradiances of UV-A (315-400 nm) and PAR (400-700 nm) received by plants in laboratory or glasshouse exposures elicit anomolously severe responses to UV-B radiation (Caldwell and Flint 1994), and screens used in filtration experiments alter several abiotic factors other than incident radiation, notably temperature and water availability (Kennedy 1995).

Experiments in locations experiencing substantial stratospheric $\mathrm{O}_{3}$ depletion are therefore required to assess plant response to $\mathrm{O}_{3}$-dependent increases in UV-B radiation. However, other than the data of Rousseaux et al. (1999) and Newsham et al. (2002), who found that $\mathrm{O}_{3}$ depletion was associated with increased foliar DNA damage in a South American herb and concentrations of foliar pigments in an Antarctic liverwort and a moss, no data exist on how $\mathrm{O}_{3}$ depletion per se influences terrestrial plants. In the light of this, a study was carried out on the Antarctic Peninsula in late austral spring and early summer to examine whether or not the pigmentation of a bryophyte, Andreaea regularis, was associated with changes to the radiative environment arising from $\mathrm{O}_{3}$ depletion. Substantial depletion of $\mathrm{O}_{3}$ occurs in the stratosphere over the Antarctic Peninsula in austral spring and summer, coinciding with the emergence of plants from melting snow and ice, resulting in wide variation in the level of solar UV-B received by vegetation. In addition, because it is uncertain whether or not flavonoids are present in the Andreaeales (Rozema et al. 1999), high performance liquid chromatography (HPLC) was used to test for the presence of these pigments in A. regularis tissues. 


\section{Materials and methods}

Irradiance and $\mathrm{O}_{3}$ column measurements

Global spectral irradiance $(280-600 \mathrm{~nm}$, step $0.5 \mathrm{~nm})$ was recorded between 16 November and 28 December 1998 by a double monochromator grating spectroradiometer (Bentham DM150; Bentham Instruments Ltd., Reading, UK) situated in a laboratory at Rothera Point, Adelaide Island, western Antarctic Peninsula (67 $34^{\prime} \mathrm{S}$, $\left.68^{\circ} 07^{\prime} \mathrm{W}\right)$. The instrument recorded data every $30 \mathrm{~min}$ between 08:00 and 19:00 hrs local time. The spectroradiometer was calibrated against a $1000 \mathrm{~W}$ quartz-halogen tungsten coil filament lamp which had been calibrated relative to National Institute of Standards and Technology standards. Data from the instrument were not available for 25 and 26 November 1998. Spectral data were either expressed as the irradiance (in W m $\mathrm{m}^{-2}$ ) of unweighted UV-B, UV-A or PAR, the irradiance of biologically effective UV-B weighted with the generalized plant action spectrum normalized at $300 \mathrm{~nm}\left(\mathrm{UV}-\mathrm{B}_{\mathrm{BE}}\right.$; Caldwell 1971), or the ratio of UV-B to PAR irradiance (hereafter $\mathrm{F}_{\mathrm{UV}-\mathrm{B}} / \mathrm{F}_{\mathrm{PAR}}$ ). Noon values of each parameter were calculated. Integration was also used to calculate daily doses (in $\mathrm{kJ} \mathrm{m}^{-2}$ ) of UV-B $\mathrm{BE}_{\mathrm{BE}}$, or unweighted UV-B, UV-A and PAR, from irradiance data. Daily mean $\mathrm{F}_{\mathrm{UV}-\mathrm{B}} / \mathrm{F}_{\mathrm{PAR}}$ values were also calculated.

Overpass measurements of $\mathrm{O}_{3}$ column depth (in Dobson Units, DU) over Rothera Point were obtained for between 16 November and 12 December 1998 from the Earth Probe Total $\mathrm{O}_{3}$ Mapping Spectrometer (EPTOMS) through the world wide web (http://jwocky.gsfc.nasa.gov). Data from the spectrometer were not available for 17 November and 13 to 28 December 1998 .

Sampling and spectrophotometric measurements

Plants of Andreaea regularis C. Muell. were sampled daily at solar noon (13:30 hrs local time) between 16 November and 28 December 1998 from a gully fed by meltwater at Rothera Point situated c. $500 \mathrm{~m}$ from the laboratory in which the spectroradiometer was located. A single colony (c. $25 \times 25 \mathrm{~mm}$ ) was excised with a scalpel each day and was placed in a clean polythene bag. There was insufficient plant material available to take replicate samples on each day.

In the laboratory, the uppermost 2-3 $\mathrm{mm}$ of foliage was cut from the colony and, to facilitate grinding, was blotted on absorbent paper until no free water could be drawn from the tissues (Post and Vesk 1992). Preliminary analyses, using the spectrophotometric methods described below, indicated that this process removed c. $2 \%$ of the pigments analysed for in this study from tissues. Each sample was then divided into three 
$100 \mathrm{mg}$ subsamples. Two of the subsamples were ground separately with $c .1 .5 \mathrm{~g}$ of silver sand in a mortar with a pestle for $0.5 \mathrm{~min}$. To extract chlorophylls and carotenoids, $3 \mathrm{ml}$ of methanol was added to the first subsample and the tissues were ground for $1 \mathrm{~min}$. The extracts were then centrifuged at $6000 \mathrm{rpm}$ for $10 \mathrm{~min}$ at $0^{\circ} \mathrm{C}$ and 700 $\mu l$ of these extracts were passed through $0.45 \mu \mathrm{m}$ filters (Whatman International Ltd., Maidstone, UK). To extract UV-B screening pigments, $3 \mathrm{ml}$ of a 70:20:1 mixture of methanol, water and $\mathrm{HCl}$ was added to the second subsample and the tissues were ground for $1 \mathrm{~min}$. The extracts were heated at 65EC for 10 min and were then centrifuged at $6000 \mathrm{rpm}$ for $10 \mathrm{~min}$, the supernatants removed and placed in a refrigerator, and a further 1 $\mathrm{ml}$ of the methanol, water and $\mathrm{HCl}$ mixture was added to the pellet, which was resuspended before heating again at $65^{\circ} \mathrm{C}$ for $10 \mathrm{~min}$ (Post and Vesk 1992). The supernatants were combined and $700 \mu$ of the extracts passed through $0.45 \mu \mathrm{m}$ filters. The third subsample was dried to constant weight $\left(60^{\circ} \mathrm{C}\right.$ for $\left.48 \mathrm{~h}\right)$ to enable pigment data to be expressed on a per g dry weight basis.

Extracts were transferred to UV grade polymethyl methacrylate semi-microcuvettes (PMMA; Kartell spa, Milan, Italy), diluted and absorbances were measured immediately in a spectrophotometer. To estimate concentrations of chlorophylls $a$ and $b$ and total carotenoids, absorbances of methanol extracts were measured at 470, 653 and $666 \mathrm{~nm}$ and concentrations of pigments calculated from standard formulae (Lichtenthaler and Wellburn 1983). Weights of chlorophylls and carotenoids extracted per g dry weight of tissue were subsequently calculated. To estimate concentrations of UV-B screening pigments, the absorbance of each acidified methanol extract was measured between 280 and $315 \mathrm{~nm}$ (step $1 \mathrm{~nm}$ ). Concentrations of UV-B screening pigments were expressed in arbitary units as the area under the absorbance curve $\left(\mathrm{AUC}_{280-315}\right)$ per $\mathrm{g}$ dry weight of tissue.

Sample preparation and analyses were conducted in dim light and were usually completed within $2 \mathrm{~h}$ of excision.

\section{HPLC analyses}

HPLC was used to test for the presence of flavonoids in A. regularis tissues. Plants collected at Rothera Point were frozen at $-80^{\circ} \mathrm{C}$ and transported to the $\mathrm{UK}$ for analysis. Tissues $(400 \mathrm{mg})$ were ground in liquid nitrogen and $1 \mathrm{ml}$ of a 50:49:1 mixture of methanol, water and $\mathrm{HCl}$ was added. The extracts were shaken in the dark overnight and injected directly onto a Prodigy ODS-3 column with a particle size of $5 \mu \mathrm{m}$ (Phenomonex,

Cheshire, UK). Flavonoids were separated by reversed phase HPLC at $30^{\circ} \mathrm{C}$ and a flow rate of $1.5 \mathrm{ml} \mathrm{min}^{-1}$. The mobile gradients were solvents A (50 mM ammonium dihydrogen orthophosphate, $\mathrm{pH} 2.5$ ) and $\mathrm{B}$ (acetonitrile) 
using the protocol described by Lunte (1987). Reagents were filtered $(0.2 \mu \mathrm{m})$ and degassed with helium. Water was purified using a Millipore milli-Q system (Millipore, Bedford, MA, USA). Spectral scans between 254 and $525 \mathrm{~nm}$ were obtained for all pigments eluted on the column by a diode array detector (Kontron Instruments Ltd., Watford, UK).

\section{Results}

$\mathrm{O}_{3}$ column and radiative environment

Data from the EP-TOMS indicated that there was wide variation in $\mathrm{O}_{3}$ column depth over Rothera Point during the period of study (Fig. 1). Taking a maximum $\mathrm{O}_{3}$ column depth of $370 \mathrm{DU}$, recorded on 19 November, a $47 \%$ reduction of $\mathrm{O}_{3}$ occurred on 3 December, when a column depth of $197 \mathrm{DU}$ was recorded over the study site. Linear regression, using $\mathrm{O}_{3}$ column depth as a predictor variable, and the calculated irradiance parameters as responses, indicated that there were no significant $(P<0.05)$ associations between $\mathrm{O}_{3}$ column depth and the irradiances or daily doses of UV-A or PAR received at ground level. However, strong inverse associations between $\mathrm{O}_{3}$ column depth and daily mean and noon $\mathrm{F}_{\mathrm{UV}-\mathrm{B}} / \mathrm{F}_{\mathrm{PAR}}$ were recorded (Fig. 1, inset; Table 1). Significant associations were also recorded between $\mathrm{O}_{3}$ column depth and the irradiances and daily doses of unweighted UV-B and UV-B ${ }_{\mathrm{BE}}$ radiation (Table 1).

\section{Plant pigmentation}

Linear regression analyses indicated that none of the $\mathrm{O}_{3}$-dependent irradiance parameters shown in Table 1 were significant predictors for concentrations of chlorophylls $a$ and $b$ or total chlorophyll (regression summary; $r^{2}=$ $0.1-7 \%$, all $P>0.05$ ). However, linear regression indicated that concentrations of UV-B screening pigments were associated with $\mathrm{O}_{3}$-dependent irradiance parameters. Concentrations of UV-B screening pigments were positively associated with increasing daily mean $\mathrm{F}_{\mathrm{UV}-\mathrm{B}} / \mathrm{F}_{\mathrm{PAR}}$ (Fig. 2a) and were also positively associated with noon $\mathrm{F}_{\mathrm{UV}-\mathrm{B}} / \mathrm{F}_{\mathrm{PAR}}$, noon irradiance of UV-B $\mathrm{B}_{\mathrm{BE}}$ and daily doses of UV-B and UV-B $\mathrm{B}_{\mathrm{BE}}\left(\right.$ Table 2 ). Daily mean $\mathrm{F}_{\mathrm{UV}-\mathrm{B}} / \mathrm{F}_{\mathrm{PAR}}$ was the most significant predictor for concentrations of UV-B screening pigments. Regression analyses indicated that concentrations of total carotenoids were positively associated with noon and daily mean $\mathrm{F}_{\mathrm{UV}-\mathrm{B}} / \mathrm{F}_{\mathrm{PAR}}(\mathrm{Fig} .2 \mathrm{~b}$; Table 2) and that noon $\mathrm{F}_{\mathrm{UV}-\mathrm{B}} / \mathrm{F}_{\mathrm{PAR}}$ was the most significant predictor for carotenoid concentrations.

Four peaks were observed on HPLC chromatograms. The strongest peak had an absorption maximum at $256 \mathrm{~nm}$ and eluted at $37.8 \mathrm{~min}$. The minor peaks had absorption maxima at 259, 263 and $260 \mathrm{~nm}$, and eluted at 
38.1, 39.0 and 39.6 min, respectively. Subsidiary absorption maxima were not observed for any of the peaks.

\section{Discussion}

The present study took place in an environment with no tropospheric $\mathrm{O}_{3}$ pollution. Therefore all variation in $\mathrm{O}_{3}$ column depth over the study site will have taken place in the stratosphere as a result of $\mathrm{O}_{3}$ depletion. The study therefore suggests that $A$. regularis responded to changes in UV-B radiation arising from stratospheric $\mathrm{O}_{3}$ depletion by increasing the synthesis of UV-B screening pigments and carotenoids in foliage. This broadly corroborates conclusions from current research into the predicted effects of $\mathrm{O}_{3}$ depletion on plant pigmentation. In a meta-analysis of plant responses to elevated UV-B radiation in 62 outdoor irradiation studies, Searles et al. (2001) found that the accumulation of foliar UV-B screening pigments was the most consistent response of plants to simulated $\mathrm{O}_{3}$ depletion. In addition, Antarctic field experiments have shown increased concentrations of UV-B screening pigments in foliage of the pearlwort Colobanthus quitensis and the grass Deschampsia antarctica exposed for four months to near-ambient solar UV-B radiation under plastic screens on the western Antarctic Peninsula, compared with plants exposed to reduced UV-B radiation (Ruhland and Day 2000; Xiong and Day 2001). The widespread accumulation of UV-B screening pigments in plant tissues in response to UV-B radiation is owing at least in part to flavonoid synthesis, caused by the induction of genes encoding chalcone synthase, a key enzyme in the flavonoid biosynthesis pathway (Jordan et al. 1994). At least some of the UV-B screening pigments in $A$. regularis foliage appear to have been flavonoids: the absorption maxima of peaks obtained on HPLC chromatograms and the absence of subsidiary maxima indicate that they were most probably flavones or biflavonyls (Harborne 1973).

Carotenoid synthesis is similarly known to be induced by exposure to UV-B radiation (Cockell and Knowland 1999). The data from the present study indicate that carotenoid concentration in $A$. regularis foliage was positively associated with increases in UV-B radiation arising from $\mathrm{O}_{3}$ depletion, corroborating the data of Xiong and Day (2001), who showed increased concentrations of these pigments in foliage of C. quitensis and D. antarctica plants exposed to near-ambient solar UV-B, compared with plants exposed to reduced UV-B. Similarly, increased carotenoid concentrations have been found in foliage of the bryophytes Cephaloziella exiliflora and Sanionia uncinata at Rothera Point during periods of $\mathrm{O}_{3}$ depletion (Newsham et al. 2002). However, no effect of elevated UV-B radiation was found on the concentrations of foliar carotenoids in the meta-analysis of Searles et al. (2001). 
The depth of $\mathrm{O}_{3}$ column above Rothera Point in the present study varied widely between days.

Therefore the time taken for pigments in A. regularis tissues to respond to changes in the radiative environment arising from $\mathrm{O}_{3}$ depletion would have been rapid, and probably $<24 \mathrm{~h}$, as has been shown for two other plant species (Newsham et al. 2002). That an Antarctic bryophyte responds rapidly to $\mathrm{O}_{3}$ depletion is perhaps surprising, given the temperature dependence of reactions in biosynthetic pathways, but the temperatures of Antarctic bryophyte colonies reach $20^{\circ} \mathrm{C}$ during cloudless periods (Newsham et al. 2002), which would enable rapid plant response to $\mathrm{O}_{3}$ depletion. The present data corroborate those from studies showing diurnal variations in foliar concentrations of carotenoids and flavonoids in alpine plant species in the natural environment (Veit et al. 1996; Wildi and Lütz 1996), and studies indicating that flavonoid production is induced within several hours of exposure to UV-B radiation (Jordan et al. 1994).

The present study suggests that chlorophyll concentration in A. regularis foliage was unaffected by UVB radiation arising from $\mathrm{O}_{3}$ depletion. Similarly, Searles et al. (2001) concluded from their meta-analysis that simulated $\mathrm{O}_{3}$ depletion has no effect on concentrations of chlorophylls in plant tissues. Altering incident UV-B radiation also has no effect on the concentrations of these pigments in C. quitensis foliage, but foliar chlorophyll concentrations in D. antarctica plants exposed to near-ambient UV-B are higher than in plants exposed to reduced ambient UV-B (Xiong and Day 2001). These findings, together with the apparent paucity of effect of elevated UV-B radiation on the maximum quantum yield of photochemistry of a wide range of plant species (Allen et al. 1998; Searles et al. 2001; Xiong and Day 2001; Newsham et al. 2002), indicate that the photosynthetic capacity of plants is unlikely to be diminished by even severe episodes of $\mathrm{O}_{3}$ depletion in the natural environment.

The data from the present study indicate that the pigmentation of $A$. regularis is significantly associated with the ratio of incident UV-B to PAR irradiance. It is widely acknowledged that this parameter is an important determinant of plant response to simulated $\mathrm{O}_{3}$ depletion (Caldwell and Flint 1994; Allen et al. 1998), possibly owing to modulation of gene expression in the flavonoid biosynthesis pathway induced by UV-B radiation and blue light (Ohl et al. 1989). Results from outdoor irradiation studies similarly indicate that the ratio of UV-B to PAR irradiance directly influences plant response in the field: Caldwell et al. (1994) found that plant growth responded most severely to elevated UV-B simulating a 36\% reduction in $\mathrm{O}_{3}$ column only when UV-A and PAR were reduced to $50 \%$ of their fluxes in solar radiation. The present data also in part corroborate the results of Caldwell et al. (1994), who found that the highest concentrations of UV-B screening pigments extracted per unit 
leaf mass were from plants exposed to elevated UV-B radiation and reduced UV-A and PAR.

The influence of carotenoids and UV-B screening pigments on the physiology of A. regularis during periods of $\mathrm{O}_{3}$ depletion is at present unclear. Carotenoids, particularly those involved in photosynthesis and photochemical quenching, are not thought to offer substantial protection from UV-B radiation, owing to the large number of carbon double bonds in these linear molecules, which tend to increase absorption in the visible portion of the spectrum (Cockell and Knowland 1999). However, UV-B screening pigments, and flavonoids in particular, efficiently absorb UV-B owing to the presence of carbon ring structures, and may hence offer significant protection to plants from UV-B radiation (Cockell and Knowland 1999). Future research is required to determine the possible benefits of carotenoids and UV-B screening pigments to A. regularis during periods of $\mathrm{O}_{3}$ depletion, for example in conferring protection on photosystem II, as has been shown for other Antarctic plant species (Newsham et al. 2002).

\section{Acknowledgments}

This work was funded by the Natural Environment Research Council. $\mathrm{O}_{3}$ data were supplied gratis by the NASA/GSFC TOMS O $\mathrm{O}_{3}$ Processing Team. Paul Geissler and Andrew Rossaak maintained the Bentham spectroradiometer, Helen Peat processed spectroradiometer data, Dom Hodgson helped with HPLC analyses and Pete Convey, Ron Lewis-Smith and two anonymous referees supplied helpful comments. Martyn Caldwell and colleagues provided preprints of papers. All are gratefully acknowledged.

\section{References}

Allen DJ, Nogués S, Baker NR (1998) Ozone depletion and increased UV-B radiation: is there a real threat to photosynthesis? J Exp Bot 49: 1775-1788

Caldwell, MM (1971) Solar UV radiation and the growth and development of higher plants. In Giese AC (ed) Photophysiology, vol 6. Academic Press, New York, pp 131-177

Caldwell MM, Flint SD (1994) Stratospheric ozone reduction, solar UV-B radiation and terrestrial ecosystems.

Climatic Change 28: 375-394 
Caldwell MM, Flint SD, Searles PS (1994) Spectral balance and UV-B sensitivity of soybean: a field experiment. Plant Cell Environ 17: 267-276 
Cockell CS, Knowland J (1999) Ultraviolet radiation screening compounds. Biol Rev 74: 311-345

Farman JC, Gardiner BG, Shanklin JD (1985) Large losses of total ozone in Antarctica reveal seasonal $\mathrm{ClO}_{\mathrm{x}} / \mathrm{NO}_{\mathrm{x}}$ interaction. Nature 315: 207-210

Harborne JB (1973) Phytochemical Methods. Chapman and Hall, London.

Jordan BR, James PE, Strid Å, Anthony RG (1994) The effect of ultraviolet-B radiation on gene expression and pigment composition in etiolated and green pea leaf tissue: UV-B-induced changes are gene-specific and dependent upon the developmental stage. Plant Cell Environ 17: 45-54

Kennedy AL (1995) Simulated climate change: are passive greenhouses a valid microcosm for testing the biological effects of environmental perturbations? Global Change Biol 1: 29-42

Lichtenthaler HK, Wellburn AR (1983) Determination of total carotenoids and chlorophylls $a$ and $b$ of leaf extracts in different solvents. Biochem Soc Trans 11: 591-592

Lunte SM (1987) Structural identification of flavonoids in beverages by liquid chromatography with ultravioletvisible and electrochemical detection. J Chromatog 384: 371-382

Newsham KK, Hodgson DA, Murray AWA, Peat HJ, Lewis Smith RI (2002) Response of two Antarctic bryophytes to stratospheric ozone depletion. Global Change Biol 8: 972-983

Ohl S, Hahlbrock K, Schäfer E (1989) A stable blue light-derived signal modulates ultraviolet light-induced activation of the chalcone synthase gene in cultured parsley cells. Planta 177: 228-236

Post A, Vesk M (1992) Photosynthesis, pigments and chloroplast ultrastructure of an Antarctic liverwort from sun-exposed and shaded sites. Can J Bot 70: 2259-2264 
Rousseaux MC, Ballaré CL, Giordano CV, Scopel AL, Zima AM, Szwarcberg-Bracchitta M, Searles PS, Caldwell MM, Díaz SB (1999) Ozone depletion and UV-B radiation: Impact on plant DNA damage in southern South America. Proc Nat Acad Sci USA 96: 15310-15315

Rozema J, van de Staaij J, Björn LO, de Bakker N (1999) Depletion of stratospheric ozone and solar UV-B radiation: evolution of land plants, UV-screens and functions of polyphenolics. In: Rozema J (ed) Stratospheric ozone depletion: the effects of UV-B radiation on terrestrial ecosystems. Backhuys Publishers, Leiden, pp 1-19

Ruhland CT, Day TA (2000) Effects of ultraviolet-B radiation on leaf elongation, production and phenylpropanoid concentrations of Deschampsia antarctica and Colobanthus quitensis in Antarctica. Physiol Plant 109: 244-251

Searles PS, Flint SD, Caldwell MM (2001) A meta-analysis of plant field studies simulating stratospheric ozone depletion. Oecologia 127: 1-10

Veit M, Bilger W, Mühlbauer T, Brummet W, Winter K (1996) Diurnal changes in flavonoids. J Plant Physiol 148: $478-482$

Wildi B, Lütz C (1996) Antioxidant properties of selected high alpine plant species from different latitudes. Plant Cell Environ 19: 138-146

World Meteorological Organization (1999) Scientific Assessment of Ozone Depletion:1998. WMO report no. 44, Geneva.

Xiong FS, Day TA (2001) Effect of solar ultraviolet-B radiation during springtime ozone depletion on photosynthesis and biomass production of Antarctic vascular plants. Plant Physiol 125: 738-751 
Table 1 Data from linear regression analyses showing the relationships between $\mathrm{O}_{3}$ column depth (as measured by EP-TOMS) and irradiance parameters recorded at ground level at Rothera Point. See Materials and Methods for details of how data were expressed in these analyses.

\begin{tabular}{|c|c|c|c|c|c|}
\hline Predictor variable & Response variable & $r^{2}(\%)$ & slope & $F_{1,23}$ & $P$ value \\
\hline \multirow[t]{6}{*}{$\mathrm{O}_{3}$ column depth } & Daily mean $\mathrm{F}_{\mathrm{UV}-\mathrm{B}} / \mathrm{F}_{\mathrm{PAR}}$ & 90.7 & $-2.2 \times 10^{-5}$ & 213.53 & $<0.001$ \\
\hline & Noon $F_{U V-B} / F_{P A R}$ & 86.0 & $-2.1 \times 10^{-5}$ & 135.08 & $<0.001$ \\
\hline & Daily dose of UV-B $B_{\mathrm{BE}}$ & 70.1 & $-3.4 \times 10^{-2}$ & 51.49 & $<0.001$ \\
\hline & Noon irradiance of $U V-B_{\mathrm{BE}}$ & 63.8 & $-1.2 \times 10^{-3}$ & 38.78 & $<0.001$ \\
\hline & Daily dose of UV-B & 52.9 & $-1.3 \times 10^{-1}$ & 24.74 & $<0.001$ \\
\hline & Noon irradiance of UV-B & 46.7 & $-4.4 \times 10^{-3}$ & 19.30 & $<0.001$ \\
\hline
\end{tabular}


Table 2 Data from linear regression analyses showing relationships between concentrations of UV-B screening pigments and carotenoids in Andreaea regularis foliage and irradiance parameters associated with $\mathrm{O}_{3}$ depletion. See Materials and Methods for details of how data were expressed in these analyses.

\begin{tabular}{|c|c|c|c|c|c|}
\hline Response variable & Predictor variable & $r^{2}(\%)$ & slope & $F_{1,29}$ & $P$ value \\
\hline \multirow[t]{4}{*}{ UV-B screening pigments } & Daily dose of UV-B $B_{B E}$ & 23.6 & $1.0 \times 10^{2}$ & 8.66 & 0.006 \\
\hline & Noon irradiance of $U V-B_{\mathrm{BE}}$ & 17.8 & $2.4 \times 10^{3}$ & 6.06 & 0.020 \\
\hline & Daily dose of UV-B & 16.9 & $1.8 \times 10^{1}$ & 5.68 & 0.024 \\
\hline & Noon $\mathrm{F}_{\mathrm{UV}-\mathrm{B}} / \mathrm{F}_{\mathrm{PAR}}$ & 16.2 & $1.6 \times 10^{5}$ & 5.43 & 0.027 \\
\hline Carotenoids & Daily mean $\mathrm{F}_{\mathrm{UV}-\mathrm{B}} / \mathrm{F}_{\mathrm{PAR}}$ & 26.0 & $7.0 \times 10^{1}$ & 9.83 & 0.004 \\
\hline
\end{tabular}


Figure legends for Newsham

Fig. 1 Variation in $\mathrm{O}_{3}$ column depth over Rothera Point during the study. Inset daily mean ratio of UV-B irradiance to PAR irradiance $\left(\mathrm{F}_{\mathrm{UV}-\mathrm{B}} / \mathrm{F}_{\mathrm{PAR}}\right)$ received at ground level at Rothera Point as a function of $\mathrm{O}_{3}$ column depth over the study site. See Table 1 for regression details. Note that axes do not extend to zero.

Fig. 2 (a) Mean concentrations of UV-B screening pigments in acidified methanol extracts, expressed as the area under the absorbance curve in the range $280-315 \mathrm{~nm}\left(\mathrm{AUC}_{280-315}\right)$, per $\mathrm{g}$ dry weight of tissue as a function of $\mathrm{F}_{\mathrm{UV}-}$ ${ }_{B} / F_{P A R}$ and (b) mean weight of total carotenoids per g dry weight of tissue as a function of $\mathrm{F}_{\mathrm{UV}-\mathrm{B}} / \mathrm{F}_{\mathrm{PAR}}$. Note that $\mathrm{F}_{\mathrm{UV}-}$ ${ }_{\mathrm{B}} / \mathrm{F}_{\mathrm{PAR}}$ values in (a) are daily means and those in (b) are noon values and that axes does not extend to zero. 


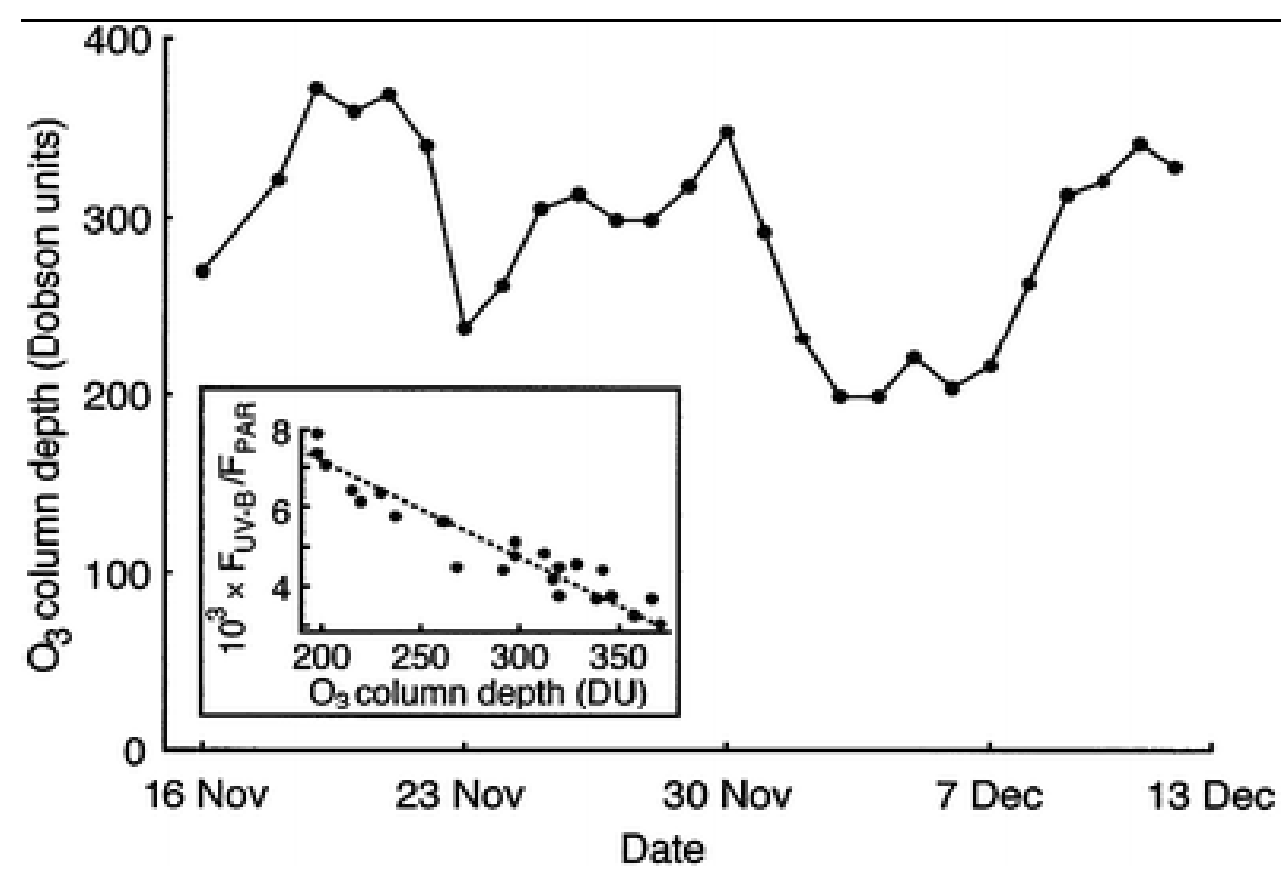

Fig. 1 

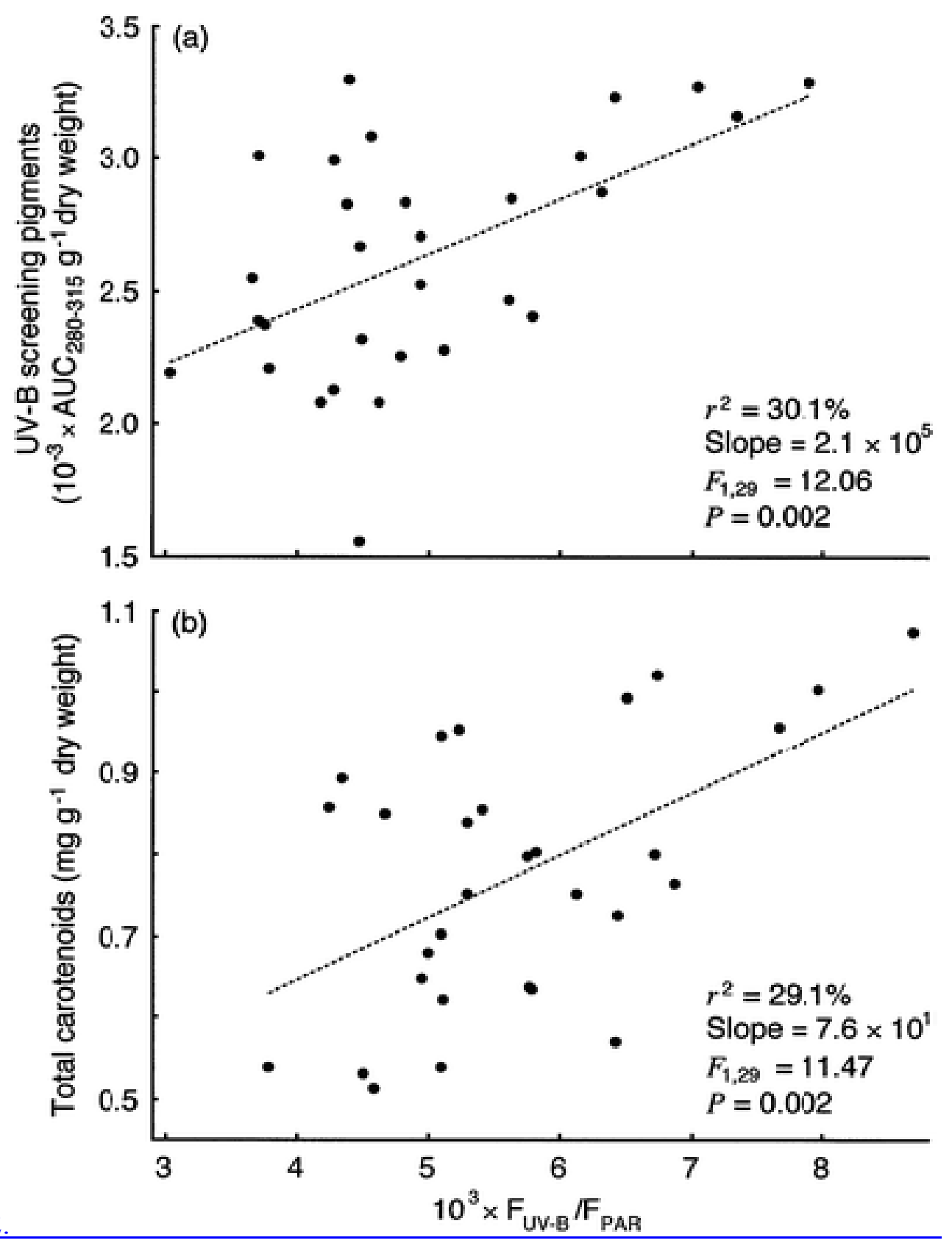